\title{
Pengaruh lingkungan terhadap gaya belajar siswa pada mata pelajaran bahasa inggris di kec. Koto xi tarusan, pesisir selatan
}

\author{
Lili Perpisa, Herviani Sevrika
}

STKIP PGRI SUMBAR Program Study Bahasa Inggris

\begin{abstract}
The aim of this research is to describe the effect of environment toward students' learning style in studying English at Kecamatan Koto XI Tarusan, Pesisir Selatan. English is an important subject for students since it has many tourism destinations. So, the students should have a capability in English in order to promote their areas. In learning English, each student has different way or different learning style. One of the factors that influences their learning style is an environment. The method of this reseach is causal-comparative. The sample used purposive sampling. The researcher chose 4 schools located in different environment; they are Junior High School number 9 located close to beach, Junior high School number 1 located close to market, Senior High School number 2 located in hilly environment, and Senior High School number 1 located between hill and beach. The total of sample is 216 students and 216 students' parents. The data were taken by using observation, questioneer and interview. The result of this research is the environment does not affect the students learning style in studying English since most of the students in 3 areas use common sense.
\end{abstract}

Key words: Environment. Learning style

\section{PENDAHULUAN}

\section{A. Latar Belakang}

Dalam proses belajar mengajar, guru dan siswa adalah komponen utama yang harus ada. Dikarenakan di dalam proses tersebut keduanya akan saling berinteraksi dan berbagi (take and give). Guru mentrasfer ilmu dan pengetahuannya kepada siswa, siswa akan menerimanya. Ketika siswa ada be keraguan tentang pemahaman ilmu yang didapat, p mereka akan berdiskusi untuk menemukan jawabannya. Selain itu guru juga berfungsi sebagai kor motivator, yang memotivasi siswa dalam belajar, sebagai facilitator yang memberikan fasilitasfasilitas belajar didalam kelas, dan sebagai
controller yang mengontrol perkembangan siswanya dalam belajar.

Pada proses belajar mengajar, guru harus menggunakan berbagai metode, teknik, strategi dan media mengajar, yang bertujuan untuk memudahkan guru menyampaikan materinya. Sehingga dengan mudah siswa dapat memahami apa yang dijelas oleh guru. Metode yang banyak digunakan diantaranya cooperative learning, contextual learning, dll, yang mana guru dan siswa sama-sama aktif didalam kelas. Sementara teknik dan strategi pengajaran pada dewasa ini sangatlah berkembang dengan pesatnya. Diantaranya, role play, envoy, grouping, herringbone, fishbone, dll. Begitu juga dengan media pengajaran, seperti; komik, gambar, diagram, vcd, power points, chart, real media dll. Semua ini dapat digunakan oleh guru dengan cara bergantian sesuai dengan karakter siswa dan materi yang diajarkan.

Selain itu, guru juga memiliki gaya mengajar yang berbeda-beda. Terkadang dengan gaya mengajar yang melekat pada dirinya, siswapun akan tahu apa yang seharusnya mereka persiapkan 
ketika masuk ke kelas. Menurut Grasha (2002:154) ada lima gaya mengajar guru, yakni; expert, formal authority, personal model, facilitator dan delegator. Guru yang menggunakan gaya mengajar expert ini adalah guru yang mempunyai ilmu pengetahuan sesuai dengan kebutuhan siswanya. Guru tersebut akan berusaha menggali kemampuan siswanya dengan cara tidak memberikan semua materi tapi hanya mentransfer bagian penting saja kemudian meminta siswanya untuk menggalinya. Gaya mengajar ini menantang siswa untuk lebih kreatif dan memiliki persiapan tentang materi yang akan mereka pelajari dikelas. Gaya mengajar formal authority, disini guru memposisikan dirinya sebagai 'faculty member' yang mana guru menjelaskan semuanya dari tujuan, target dan materinya. Lain lagi dengan gaya mengajar personel model, gaya ini menuntut guru sebagai contoh dari semua aktifitas dan tingkah laku di dalam kelas. Sedangkan gaya mengajar facilitator, guru lebih menekankan kepada hubungan personal guru dengan siswa secara alami. Terakhir, gaya belajar delegator, guru berusaha meningkat kemampuan siswa secara personal dengan memberikan tugas-tugas yang harus diselesaikan oleh siswanya. Berbagai gaya mengajar ini dapat di aplikasikan oleh guru dikelas tergantung juga bagaimana siswanya.

Namun, tidak hanya guru yang memiliki strategi-strategi dalam mengajar, siswapun juga harus memiliki strategi atau gaya belajar yang akan membantu memahami pelajaraan secara efektif. Setiap siswa memiliki strategi atau gaya belajar yang berbeda. Sebagaian siswa didalam kelas lebih cendrung menulis materi pelajaran tanpa mau mendengarkan penjelasan gurunya. Sebagian lagi ada juga yang lebih menyukai mendengar saja tanpa mau mencatat materi yang disampaikan. Ada juga yang melakukan keduanya dalam waktu bersamaan, sambil mendengarkan mereka juga menulis atau sebaliknya. Gaya belajar siswa dirumahpun juga berbeda-beda sesuai dengan karakternya masingmasing. Ada yang belajar sambil mendengar musik kegemaranya, ada juga yang lebih suka sendiri tanpa ada suara apapun supaya tidak terganggu kosentrasinya atau ada yang suka belajar bersama teman-teman (berkelompok). Jadi gaya belajar ini tergantung kepada siswa itu sendiri.

Selain karakter seseorang yang mempengaruhi gaya belajarnya, lingkungan juga ikut berpengaruh, baik lingkungan keluarga maupun lingkungan sekitarnya. Siswa yang tinggal di lingkungan keluarga yang baik-baik akan berbeda gaya belajarnya dengan siswa yang berasal dari keluarga broken home. Siswa yang tinggal didekat pasar akan memiliki gaya belajar berbeda dengan siswa yang jauh tinggal dari keramaian. Begitu juga siswa yang tinggal dekat gunung akan memiliki gaya belajar yang berbeda dengan siswa yang tinggal di tepi pantai.

Kecamatan Koto XI Tarusan merupakan salah satu kecamatan di kabupaten Pesisir Selatan, Sumatera Barat. Kecamatan ini terletak paling utara Pesisir Selatan, yang di awali dari siguntur sampai kapuh. Daerah-daerah tersebut ada yang berada dekat perbukitan dan sungai, ada juga Di daerah ini mempunyai 7 Sekolah Menengah Pertama dan 2 Sekolah Tingkat Atas. 6 dari sekolah tersebut terletak dekat pantai dan 3 lainnya berada di daerah perbukitan Tarusan. Masing-masing sekolah memiliki karakteristik siswa yang berbeda. Dengan karakter yang berbeda tersebut, masingmasing sekolah juga mempunyai prestasi yang berbeda juga. Salah satu faktor yang menyebabkan perbedaan ini adalah gaya belajar siswanya.

Salah satu kelebihan daerah Koto XI Tarusan ini adalah kaya dengan asset alamnya yang indah yang dijadikan sebagai salah satu tempat tujuan wisata di Indonesia. Dilihat dari indahnya aliran Sungai Batang Tarusan dari Siguntur sampai pasar Tarusan, Pantai Batu Kalang, Carocok, Mandeh, Pantai Muaro Pulau Karam, Pulau Cubadak, Pulau Setan, dll. Semua daerah ini berpotensi sebagai daerah wisata yang dapat dikunjungi, tidak hanya untuk turis lokal tapi turis mancanegara yang setiap tahunnya semakin meningkat. Contohnya, pulau cubadak, sebagian besar pengunjungnya adalah turis mancanegara. Untuk sampai kesana dari kota harus melewati beberapa daerah wisata lainnya. Melihat asset wisata yang sangat bagus ini, bahasa Inggris merupakan salah satu komponen penting yang harus di miliki oleh penduduk setempat dalam rangka untuk mengenalkan wilayahnya keluar.

Pada pendidikan formal Bahasa Inggris merupakan mata pelajaran wajib untuk sekolah tingkat menengah dan tingkat atas. Mata pelajaran ini diujikan pada ujian nasional. Untuk itu siswa dituntut untuk menguasai empat skill yakni; listening, speaking, reading and writing. Disekolah keempat skill ini dipelajari secara menyeluruh. Dalam belajar bahasa Inggris ini, siswapun mempunyai gaya belajar yang berbeda, baik ketika 
belajar mendengar, berbicara, membaca dan menulis. Dengan menguasai bahasa ini diharaapkan dapat mempromosikan wilayah wisata dan meningkatkan kualitas diri.

Menyikapi fenomena tersebut, penulis tertarik untuk meneliti Pengaruh Lingkungan terhadap gaya belajar siswa pada mata pelajaran Bahasa Inggris di Kecamatan Koto XI Tarusan

B. Rumusan Masalah

Berdasarkan masalah diatas, maka penelitian ini di rumuskan;

1. Bagaimana kondisi lingkungan tempat tinggal siswa di Kecamatan Koto XI Tarusan, Pesisir Selatan?

2. Apakah tipe-tipe Gaya Belajar yang digunakan siswa pada mata pelajaran Bahasa Inggris di sekolah di Kecamatan Koto XI Tarusan?

3. Bagaimana Pengaruh lingkungan terhadap gaya belajar siswa pada mata pelajaran bahasa Inggris di Kecamatan Koto XI Tarusan?

\section{TINJAUAN PUSTAKA}

A. Lingkungan Belajar

Lingkungan merupakan tempat dimana siswa hidup dengan yang lainnya. Sehingga lingkungan sangat mempengaruhi gaya belajar siswa. Untuk itu lingkungan terbagi atas tiga bagian yaitu:

1. Lingkungan keluarga

Lingkungan keluarga adalah segala kondidsi dan pengaruh dari luar terhadap kehidupan dan perkembangan anggota keluaraga

(Tirtarahardja dan Lasulo, 1994:173)

Kemudian menurut slamento, gaya belajar akan dipengaruhi oleh cara orang tua mendidik, relasi antara anggota keluarga, suasana rumah, keadaan ekonomi keluraga, pengertian orang tua dan latar belakang kebudayaan.

2. Lingkungan sekolah

Lingkungan sekolah merupakan lembaga pendidikan formal, dimana siswa menuntut ilmunya. Menurut slamento, pada lingkungan sekolah ada beberapa faktor yang akan mempengaruhi gaya belajar anak diantaranya: metode mengajar, kurikulum, relasi guru siswa, siswa-siswa, dan disiplin sekolah, alat belajar, waktu sekolah, standar pelajaran, tugas rumah, dan sarana prasarana.

3. Lingkungan masyarakat

Lingkungan masyrakat adalah tempat orangorang hidup bersama yang berpengaruh besar terhadap perkembangan siswa (Slameto, 2004). Diantarnya kegiatan siswa dalam masyrakat, teman bergaul, dan bentuk kehidupan masyuarakat. Apabila siswa berkembang dilingkungan yang baik maka akan berpengaruh baik juga terhadap diri siswa (Slameto, 2004). Contohnya, apabila seorang siswa tinggal dilingkungan pantai yang orang tuanya melaut maka terkadang anaknya ikut juga mekmbantu untuk menopang kehidupan ekonomi keluarganya sehingga kan menyita waktu belajar siswa dan juga akan mempoengaruhi gaya belajarnya.

Dalam penelitian ini, peneliti lebih memfokuskan kepada masyarakat dimana siswa itu tinggal yang berdasarkan letak geografis kecamatan Koto XI Tarusan itu sendiri, yang di mulai dari utara sampai ke selatan.

\section{B. Gaya Belajar}

Gaya belajar merupakan tindakan yang selalu digunakan seseorang dalam belajar Sebagaimana pendapat Honey dan Mumford (1992:1), gaya belajar adalah deskripsi dari tingkah laku seseorang yang lebih sering dilihat ketika belajar. Setiap siswa mempunyai gaya belajar yang berbeda-beda, menurut De Porter dan Mike (2005:28), secara umum ada tiga macam gaya belajar siswa, yakni:

1. Visual. Siswa yang menggunakan gaya belajar visual ini, biasanya lebih cendrung menerima informasi atau pelajarn dalam bentuk gambar, table, grafik, peta konsep atau symbol-simbol.

2. Auditorial. Sedangkan untuk siswa yang memiliki gaya belajar auditorial lebih senang jika pembelajarn dilakukan dalam bentuk lagu atau syair.

3. Kinestetik. Untuk siswa yang menggunakan gaya belajar kinestetik akan lebih mudah menerima pelajaran yang diiringi aktivitas motorik, seperti bermain peran atau pratikum di labor. 
Pendapat diatas juga didukung oleh D.Lefever (2004:95), ia berpendapat bahwa gaya belajar siswa ada tiga method, yaitu metode melihat, metode mendengar, metode bergerak. Konsep dari ketiga metode ini sama dengan VAK. Lain halnya dengan pada Diaz-Rico (2004:110) yang didalam bukunya menjelaskan berbagai macam tipe-tipe gaya belajar dari beberapa ahli pendidikan, seperti Hruska-Rieccmannn dan Garsha, keefe, Sonbucher, Trap, Kolp,McCarthy, Gregorc dan Myres/Briggs.

Berdasarkan Hruska-Reichmann and Grasa, gaya belajar ini ada tiga kelompok juga, tetapi ketiganya memiliki lawan masing-masing, yaitu; Competitive dengan cooperative, independent dengan dependent, participant dengan avoidant. Berdasarakan bentuk gaya belajar siswa diatas, terlihat jika sebagain siswa itu ada yang mempunyai gaya belajar yang berpacu untuk menjadi lebih baik, ada juga yang belajarnya lebih cendrung bekerjasama dengan teman-temannya. Bentuk yang lainnya, ada yang gaya belajarnya tergantung kepada orang lain disekitarnya atau orang lain yang memotivasi. Ada juga dengan kesadaran sendiri mau belajar. Bentuk lainnya, ada yang aktif dan ada yang juga yang tidak mau melibatkan dirinya didalam proses belajar itu sendiri.

Kemudian seorang pendidik Mc.Carthy membagi atas empat gaya belajar, yaitu:

1. Imaginative learner

Siswa yang menggunankan gaya belajar imajinative adalah siswa yang belajar dengan rasa dan perasaan, memperhatikan keadaan disekelilingnya dan melihat segala sesuatu dari sesuatu dari semua sudut pandang. Kemudian siswa ini juga merupakan orang-orang yang penuh ide dan lebih menyukai pertanyaan yang membutuhkan penjelasan, seperti pertanyaan yang dimulai dengan mengapa. Tetapi siswa imaginative ini cendrung emosional dalam belajar.

2. Analytic learner

Analytic Learner adalah belajar dengan memperhatikan dan mendengarkan. Disini guru menjadi sumber informasi utama. Siswa tersebut akan duduk dengan baik mendengarkan penjelasan dari guru. Siswa yang menggunakan gaya belajar ini biasanya disebut siswa yang baik didalam kelas karena siswa ini mampu mengkoseptualisasikan sesuatu dengan cara merefleksikan dan memikirkan dengan cara yang teratur. Sehingga tipe ini disebut dengan perencana yang baik dan lebih rasionalitas. Tipe ini tidak seemisional innovator.

\section{Common Sense Learner}

Common Sense Learner merupakan siswa yang lebih suka bermain dengan ide-ide yang rasional dan dapat dibuktikan. Mereka belajar dengan menkombinasikan bekerja. Mereka dapat memecahkan masalah secara aktif, belajar melalui pencarian dan tugas-tugas. Siswa dengan tipe ini lebih cendrung memecahkan masalah sendiri, dan menguji apapun dengan secara fisik. Mereka juga lebih menikmati persaingan, tetapi toleransi terhadap hal-hal yang tidak berhubungan dengan mereka agak rendah, karena lebih berorientasi pada berpikir dan sistematis dalam belajar.

4. Dynamic Learner

Lain halnya dengan dynamic learner, siswa akan lebih cendrung bertindak dari pada berpikir. Mereka mau mengambil resiko. Sehingga tipe ini terkesan ambisius dan antusias. Namun mereka dapat dengan mudah menyesuaikan diri dengan perubahan.

Dalam penelitian ini, peneliti menggunakan tipe-tipe belajar Mc.Carthy karna empat tipe ini lebih spesifik dan banyak ditemukan pada usia siswa yang akan beranjak dewasa, SMP dan SMA.

\section{METODE PENELITIAN}

Penelitian ini merupakan penelitian causalcomperative study. Didalam penelitian ini peneliti ingin menjelaskan tentang pengaruh keadaan lingkungan dimana siswa tinggal terhadap. gaya belajar yang digunakan oleh siswa tersebut didalam belajar bahasa Inggris.. Menurut pendapat Mc.Millan and Sally (2001:33) menyatakan bahwa penelitian causal-comperative ini merupakan penelitian yang mengkaji adanya perpedaan antara dua grup atau lebih yang akan di bandingkan. Kedua grup atau variablenya tidak dapat di manipulasi karna keduanya sudah ada dan terjadi. Menurut Gay and Airasian (2000:248) penelitian terkadang seperti penelitian descriptive karna mendeskripsikan kondisi yang telah ada. Didalam 
penelitian ini lingkungan siswa tinggal dan gaya belajar siswa sebagai variablenya.

Instrument yang telah digunakan dalam penelitian ini adalah; lembaran observasi, angket yang memuat pertanyaan tentang gaya belajar yang digunakan oleh siswa dalam belajar bahasa Inggris dan lembaran interview orang tua siswa tentang keadaan lingkungan dan gaya belajar siswa baik dirumah maupun di sekolah.

Sampel yang digunakan dalam penelitian ini adalah purposive sampling. Peneliti memilih sample sesuai dengan kebutuhan pada penelitian ini. Maka SMPN 1 Tarusan, SMPN 9 Tarusan, SMAN 1 Tarusan, dan SMAN 2 Tarusan dipilih sebagai sampelnya karna keempat sekolah ini terletak pada lingkungan yang berbeda-beda

Pada penelitian ini, data dianalisa dengan cara deskriptive dan inferential satitistik.

\section{PEMBAHASAN DAN HASIL}

\section{Keadaan Lingkungan Tempat Tinggal Siswa di Kecamatan Koto XI Tarusan.}

Data awal tentang keadaan lingkungan tempat tinggal siswa ini telah didapat melalui observasi dan interview. Pada Bulan mei 2013, peneliti melakukan observasi ke kecamatan Koto XI Tarusan. Didapatlah bahwa siswa-siswa SMP dan SMA yang ada di kecamatan ini tinggal di dari utara daerah Siguntur sampai yang paling selatannya Kapuh. Wilayah paling utara merupakan lingkungan perbukitan, sekolah yang ada disana adalah SMPN 5 Tarusan dan SMAN 2 Tarusan. Tetapi pada penelitian ini peneliti hanya memilih SMAN 2 saja karena disini siswanya berarasal dari dalam kecamatan itu sendiri. Sedangkan SMPN 5 karena terletak didekat batas, maka siswanya banyak dari luar kecamatan ini. Sementara pada daerah ibu kecamatan pasar Tarusan merupakan lingkungan pasar. Seakolah yang berada dekat dengan lingkungan pasar ini adalah SMPN 1 Tarusan. Bagian dari selatan kecamatan ini merupakan daerah pantai yang padat penduduknya. Sekolah yang berada pada lingkungan pantai ini adalah SMPN 9 Tarusan, mayoritas siswanya adalah anak pesisir pantai yang orang tuanya sebagai nelayan. Sekolah yang paling selatannya adalah SMAN 1 Tarusan. Lingkungan sekolah diapit oleh dua lingkungan yang berbeda, karena dekat dengan pantai bagian depan sekolah, sedangkan dibelakang sekolah ada pebukitan sabai nan aluih.

Data ini diperkuat oleh hasil wawancara dengan orang tua siswa yang memberikan gambaran tentang tempat tinggalnya melalui pertanyaan peneliti berapa jarak rumah mereka dari pantai, pasar dan pebukitan. Wawancara ini dilakukan pada bulan September 2013 dari tanggal 1 sampai 15 dengan 215 orang tua siswa. Sebagai petunjuk sebelum wawancara, peneliti mendapat informasi tempat atau lokasi yang dituju dan nama orang tua siswa yang akan diwawancari melalui angket yang disebarkan pada bulan juni dan agustus 2013 di sekolah-sekolah tersebut. Angket disebarkan keempat sekolah sebanyak 216 lembar, tetapi ada satu siswa yang tidak mengisi nama orang tuanya. Jadi ketika wawancara hanya 215 orang saja.

Berdasarkan data yang tersebut, maka didapat tiga jenis lingkungan tempat tinggal siswa di kecamatan Koto XI Tarusan: Lingkungan pantai, Lingkungan pasar dan Lingkungan perbukitan. Masing-masing siswa dikelompokkan berdasarkan lingkungannya. Adapun siswa yang bertempat tinggal di lingkungan pantai berjumlah 87 orang, di lingkungan pasar berjumlah 51 orang, sedangkan di lingkungan perbukitan terdapat 77 orang. Masingmasing lingkungan ini memiliki karakter yang berbeda secara teoritisnya. Pada lingkungan pantai, suasana belajar di siang hari dan malam hari akan berbeda dibanding lingkungan lainya. Karna pada siang hari, penduduk yang ada disekeliling tempat tinggal siswa akan lebih ramai karna rata-rata mata pencariannya adalah nelayan yang dilakukan pada malam hari. Pada saat bulan terang, nelayan tidak dapat bekerja, sehingga malamnya akan terasa lebih ramai dibanding malam yang lainnya. Berdasarkan wawancara dengan orang tuanya, siswa - siswa yang berada pada lingkungan ini lebih banyak belajar ketika mereka akan ujian saja. Pada harihari biasa, mereka lebih banyak menghabiskan waktunya dengan aktivitas lain yang berhubungan dengan handphone atau kalau ada acara kesenian seperti orgen tunggal. Sementara pada lingkungan pasar, baik siang maupun malam suasananya samasama ramai. Sedangkan pada lingkungan perbukitan memang terkesan lebih sunyi pada siang dan malamnya. Tetapi siswa-siswa di sana pada siang hari lebih banyak menghabiskan waktunya di sekolah. 
B. Tipe-Tipe Gaya Belajar Siswa Pada Mata Pelajaran Bahasa Inggris di Kecamatan Koto XI Tarusan

Data tipe-tipe gaya belajar siswa pada mata pelajaran bahasa Inggris ini didapat melalui angket yang disebarkan di 4 sekolah yakni SMAN 1 Tarusan sebanyak 52 angket pada tanggal 20 Agustus 2013 dan di SMPN 1 Tarusan pada tanggal 21 Agustus 2013 dengan jumlah 65 angket, tetapi 2 angket diisi semua pilihannya jadi yang bisa di gunakan hanya 63 angket. Tetapi surat keterangan telah melakukan penelitiannya dikeluarkan pada bulan September 2103. Di SMPN 9 Tarusan sebanyak 50 angket tetapi ada 2 siswa yang tidak mengisinya. Ini dilaksanakan pada tanggal 25 Agustus 2013. Di SMAN 2 Tarusan sebanyak 50 angket 50 pada tanggal 26 Agustus 2013 (lampiran 1).

Berdasarkan lingkungan diatas, peneliti menggelompokkan siswa berdasarkan gaya belajarnya. Seperti diagram dibawah ini;

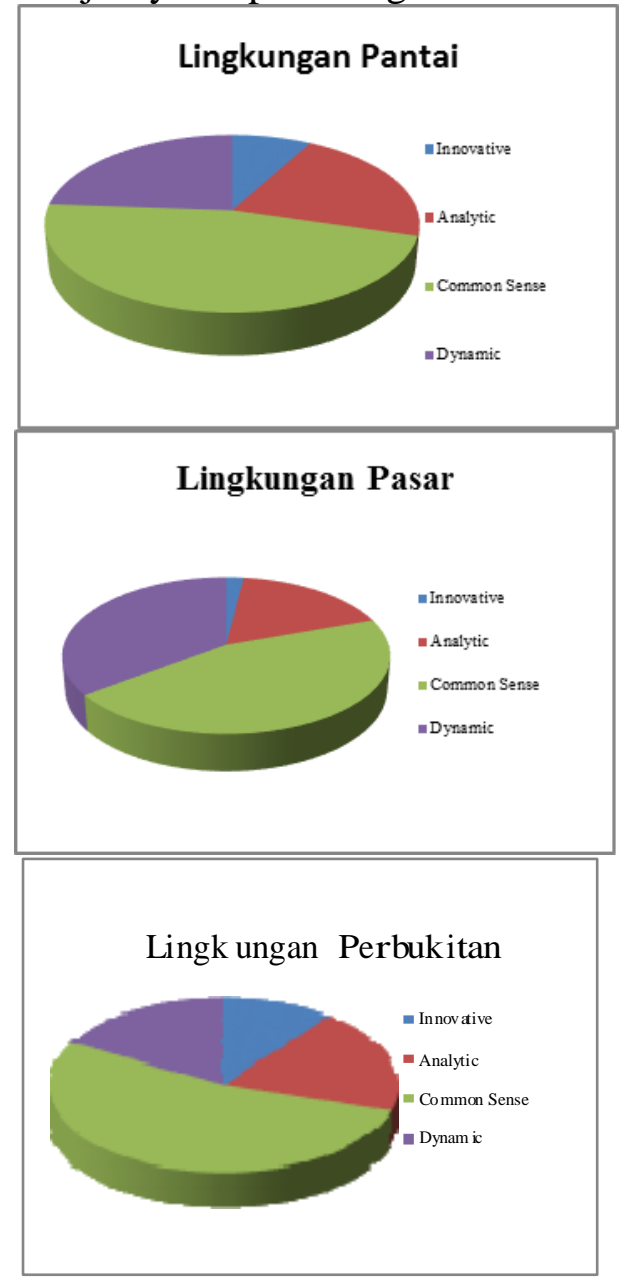

Dapat dilihat bahwa dari siswa yang tinggal di lingkungan pantai (88 orang), ada 7 orang $(7,95 \%)$ menggunakan gaya belajar Innovative dalam belajar bahasa Inggris, 19 (21,59\%) orang menggunakan gaya belajar Analytic, dan 41 orang $(46,59 \%)$ memiliki gaya belajar Common Sense, dan 21 orang $(23,86 \%)$ menggunakan gaya belajar Dynamic dalam belajar bahasa Inggris. Sedangkan pada lingkungan pasar hanya 1 orang $(1,96 \%)$ yang memiki gaya belajar Innovative ketika belajar bahasa Inggris dari 51 siswa, 9 orang yang memiliki gaya belajar analytic. Sedangkan gaya belajar common sense pada saat belajar bahasa Inggris dimiliki oleh 23 orang. 18 orang lagi memilki gaya belajar Dynamic. Terakhir pada lingkungan perbukitan didapat 8 orang yang memiki gaya belajar Innovative ketika belajar bahasa Inggris, 15 orang yang memiliki gaya belajar analytic. Sedangkan gaya belajar common sense pada saat belajar bahasa Inggris dimiliki oleh 41 orang. 13 orang lagi memilki gaya belajar Dynamic. Jika dilihat dari ketiga diagram tersebut, ketiganya memiliki persamaan, yakni gaya belajar common sense mendominasi pada ketiga lingkungan.

\section{Pengaruh Lingkungan Terhadap Gaya Belajar Siswa pada Mata Pelajaran Bahasa Inggris}

Baik lingkungan pantai, pasar maupun perbukitan ada bentuk gaya belajar yang sama yang dimiliki oleh siswa. Ketiganya menggambarkan bahwa pada siswa-siswa SMP dan SMA yang tinggal di kecamatan Koto XI Tarusan, walaupun memiliki lingkungan tempat tinggal yang berbeda, mereka memiliki kecendrungan gaya belajar yang sama yaitu; Common Sense. Sementara itu gaya belajar kedua yang banyak juga digunakan oleh siswa pada setiap lingkungan diatas adalah dynamic. Gaya belajar Innovative dan Analitic hanya sedikit digunakan oleh siswa ketika belajar bahasa Inggris. Common sense merupakan gaya belajar yang mana siswa tidak hanya sekedar berpikir saja, tetapi mereka lebih cendrung langsung bertindak. Sesuatu yang berhubungan dengan hal-hal yang nyata merupakan pilihan topik yang tepat untuk mereka pelajari. Ini sesuai dengan usia mereka 13-19 tahun. Ini usia perkembangan anak pada tahap pendewasaan dirinya. Jadi mereka tidak mau sesuatu yang tidak nyata lagi, contohnya ketika 
membaca sebuah teks, mereka akan memilih sebuah cerita yang dapat mereka buktikan dibanding cerita dongeng yang menurut mereka itu hanya cocok untuk anak kecil. Kemudian jiwa berkompetisinya sangat tinggi. Hal ini menyebabkan mereka lebih cendrung menyelesaikan permasalahannya secara individu, sehingga rasa toleransinya berkurang. Ini dapat dikatakan bahwa tempat tinggal siswa di kecamatan Koto XI Tarusan, lingkungan pantai, pasar dan perbukitan tidak mempengaruhi gaya belajar siswa pada mata pelajaran bahasa Inggris.

Hal ini juga dibuktikan melalui hitungan regresi sederhana,Jika $F_{\text {hitung }}$ lebih kecil dari $F_{\text {tabel, }}$ maka $\mathrm{H}_{\mathrm{i}}$ di tolak dan $\mathrm{H}_{0}$ yang diterima, $\mathrm{F}_{\text {hitung }}=-$ $214,09, \mathrm{~F}_{\text {tabel }}=3,89$, artinya tidak ada pengaruh lingkungan terhadap gaya belajar siswa pada mata pelajaran bahasa Inggris di kecamatan Koto XI Tarusan.

\section{KESIMPULAN DAN SARAN}

Penelitian ini dapat disimpulkan bahwa tidak adanya pengaruh lingkungan terhadap gaya belajar siswa pada mata pelajaran bahasa Inggris di kecamatan Koto XI Tarusan karena dari ketika lingkungan yang didapatkan baik lingkungan pantai, pasar dan perbukitan, siswa lebih cendrung menggunangkan gaya belajar common sense. Ini artinya dalam belajar bahasa Inggris, siswa-siswa tersebut tidak hanya suka memikirkan sesuatu yang tidak jelas dalam belajar bahasa Inggris, mereka juga suka langsung melakukan dan berhungan dengan hal-hal yang nyata. Hal ini berkemungkinan disebabkan karena usia mereka yang berkisar 13 tahun - 19 tahun. Usia ini adalah usia yang masih mau mencoba sesuatu hal yang baru. Sehingga pada gaya belajar ini siswa cendrung individualis dan mengerjakan tugas-tugas secara mandiri. Dilihat dari lingkungan yang berbeda, dengan fasiltas teknologi yang didapat dari semua lingkungan, menjadikan siswa-siswa di kecamatan ini memiliki gaya belajar yang cendrung sama.

Dari penelitian ini, disarankan untuk guru-guru SMP dan SMA di kecamatan Koto XI Tarusan untuk dapat memilih strategi pengajaran yang tepat dalam mentransfer ilmu dan pengetahuannya, khususnya dalam mengajar bahasa Inggris. Dari hasil penelitian ini disarankan juga untuk tidak membedakan lagi siswa yang berasal dari lingkungan tempat tinggal yang berbeda.

\section{REFERENCES}

\section{REFERENCES}

[1] Dahar, Ratna Willis. 1998. Teori - Teori Belajar. Dept. Pendidikan dan Kebudayaan DIRJEN Perguruan Tinggi. Proyek Pengembangan Lembaga Tenaga Kependidikan.

[2] D, Lefever, Marlene. 2004. Creative Teaching Methods. Barcelona: Kindle.

[3] De Porter, Bobbi dan Mike Hernarchi. 2001. Quantum Learning: Membiasakan Belajar Nyaman dan Menyenangkan. Bandung: Penerbit Kaifa.

[4] Diaz-Rico, Lynne T. 2004. Teaching English Learners. Strategies and Method. California: Pearson Education Inc

[5] Gay, L.R and Peter Airasian. 2000. Educational Research: Competencies for Analysisi and Application. New Jersey: Prentice-Hall Company.

[6] Grasha F, Anthony. 2002. Teaching with Style: A Practical Guide to enhancing Learning by Understanding Teaching and Learning Styles. San Bernadino: Alliance Publisher.

[7] Hakim, Thursan. 2000. Belajar Secara Effektif: Panduan Menemukan Teknik Belajar, Memilih Jurusan, dan Menemukan Cita - cita. Jakarta: Puspa Swara.

[8] Hergenhahn, B.R. and Mattew H.Olson. 2009. Theories of Learning (Teori Belajar). Jakarta: Kencana

[9] Kenihilir, Dirk, Poblo Pirnay, Dummer I. Michael Spector. 2008. Understanding Models for Learning and Instruction. New York: Springer.

[10] Mc.Millan, James and Sally Schumacher. 2001. Reseach in Education A Conceptual Introduction. New York: Longman inc

[11] Slameto. 2003. Belajar dan Faktor-Faktor yang Mempengaruhinya. Jakarta: PT. Rineka Cipta

[12] Sudjana, Nana and Ibrahim. 2011. Penelitian dan Penilian Pendidikan. Bandung: Sinar baru Algensindo.

[13] Tirtaraharja, Umar dan La Sulo. 1994. Pengantar Pendidikan. Jakarta: Depdikbud.

[14] Uhl Chamot, Anna and .1999. The Leraning Stategies. Longman; 